\title{
A systems perspective as a tool to understand disruption in travel and tourism
}

\author{
Albert Postma and lan Seymour Yeoman
}

\begin{abstract}
Purpose - The purpose of this paper is to contribute to the understanding of systems thinking and its value for strategic foresight and scenario planning to address disruptive forces from the outside, with the outbreak of COVID19 as a case study.

Design/methodology/approach - This conceptual paper concisely discusses the notion of systems thinking and the concept of complex adaptive systems and puts this in the context of contemporary society in general and travel and tourism in particular. Strategic foresight and scenario planning are introduced as an approach to anticipate disruptions in the complex adaptive travel and tourism system.

Findings - As COVID-19 has demonstrated, travel and tourism is sensitive for disruptions from the outside. To ensure long-term resilience and sustainability, a systems approach embedded in strategic foresight and scenario planning is emphasised.

Practical implications - Strategic foresight and scenario planning is a competence that can be learned. Originality/value - Given the present status of COVID-19 and other disruptors on travel and tourism, a resilient approach to the future is necessary; thus, the value of this viewpoint paper is the proposition of an adaptive capacity system. This paper offers advice to understand and manage complexity and adaptive systems.
\end{abstract}

Keywords Travel and tourism, COVID-19, Systems thinking, Complex adaptive systems, Disruptions, Foresight

Paper type Viewpoint

\section{Introduction}

Since the COVID-19 outbreak in December 2019, the tourism industry has come to a halt. Every country in the world according to the UNWTO (2020) has adopted measures and restrictions to stop the spread of the disease. Such measures have been unprecedented in tourism policy. In the beginning, tourism industry professionals neglected the seriousness of the potential consequences of the COVID-19 outbreak (Pratt, 2020), while European travellers still went to Italy for their winter sports holiday (Grech, 2020). Like many collapse scenarios (Dator, 2009), COVID-19 was treated initially with a degree of scepticism. Remember President Trump's saying (Jane, 2020) [...].

The risk to the American people remains low [...]. But that's a little bit like the flu. It's a little like the regular flu that we have flu shots for [...] [...].The risk to the American people remains very low.

In fact, COVID-19 could be interpreted as the "decline point" in the classic life cycle model, at which Dator's "decline and collapse" future starts to unfold. This future perspective is characterised by an emerging crisis that causes failure or degradation of the system (Dator, 1981, 2002; Bezold, 2009).

The question is how the industry could be prepared for powerful external forces such as the COVID-19 outbreak. With hindsight, we look back and analyse and interpret historical data
Albert Postma is based at

the European Tourism

Futures Institute (ETFI), NHL Stenden University of Applied Sciences, Leeuwarden, The Netherlands. Ian Seymour Yeoman is based at Wellington School of Business and Government, Wellington, New Zealand and the European Tourism Futures Institute (ETFI), NHL Stenden University of Applied Sciences, Leeuwarden, The Netherlands.

Received 9 April 2020 Revised 25 November 2020 Accepted 1 December 2020

C) Albert Postma and lan Seymour Yeoman. Published in Journal of Tourism Futures. Published by Emerald Publishing Limited. This article is published under the Creative Commons Attribution (CC BY 4.0) license. Anyone may reproduce, distribute, translate and create derivative works of this article (for both commercial and non-commercial purposes), subject to full attribution to the original publication and authors. The full terms of this license may be seen at http://creativecommons. org/licences/by/4.0/legalcode 
that have led to the crisis. As an alternative to this retrospective sensemaking, foresight is used for prospective sensemaking. Hindsight and foresight fundamentally differ in the information to be used (MacKay and McKiernan, 2004; MacKay and Parks, 2013). Foresight makes use of scenarios to envision multiple futures that tourism may be faced with. When these scenarios are used to inspire long term policies by businesses or organisations, it is referred to as strategic foresight.

Hindsight, looking back, may distort our ability to understand the future. Faulty interpretations may cause bias, but we may also overestimate what we could have known at the time of the event, especially in the case of crises: in retrospect it is rather easy to list signals that could have warned us beforehand (MacKay and McKiernan, 2004; Nathan, 2004). In this viewpoint paper we take a foresight perspective. We will start with discussing systems thinking, as one of the key principles of strategic foresight and scenario planning (Lindgren and Bandhold, 2009). Next, we will turn to the benefits of the systems approach to understand the functioning of our society in general and of travel and tourism in particular. We will end with reflecting how strategic foresight and scenario planning, and its assumption of systems thinking, can be used to understand travel and tourism better, and to be better prepared for powerful forces from the outside.

\section{Systems thinking}

A systems approach helps to order and collect knowledge, to understand the behaviour of a system and to identify measures with which the system van be maintained or changed and thus to act more effectively. The analytical approach is focussed on the elements of a system and their interactions. It assumes that the relations between the components are stable and static. Contrary to the analytical approach, the systems approach is focussed on the totality, complexity and dynamics of a system and the consequences of interactions. The analytical approach is too limited to describe the real world and to explain a wide array of phenomena (Baggio, 2008), while the systems approach does enable to comprehend and describe organised complexity (Baggio, 2008). This approach is transdisciplinary and integrates viewpoints from disciplines such as biology, information theory, cybernetics and systems theory. Systems thinking was developed between the 1940s and the 1970s, predominantly by Massachusetts Institute of Technology (MIT) (De Rosnay, 1975).

Characteristic for a system is that it consists of a large number of components or elements and their interrelations. The components and their interrelations and the border of the system are structural features of the system. Next to structural characteristics each system does also have temporal or functional attributes. These refer to for example exchange between the system and its environment, the interactions between the components in the form of positive or negative feedback loops, and the consequential evolution of the system into a certain direction, such as growth or decay. Systems can be open to or closed from the environment. A closed system does not exchange any energy, nor matter with its environment. It gradually burns its energy, which ultimately results in its decay. Contrarily, an open system is in continuous interaction with its environment and, to maintain itself, it taps energy and matter from and returns waste (entropy) to its environment. Positive feedback causes change, such as growth and evolution. A snowball effect causes the system to diverge, both in the number and diversity of components and interactions and/or in energy levels. This may lead to continued expansion of the system, total explosion or blockade of all its activities and functions. Negative feedback results in regulation and stability, rebalancing and convergence towards a certain level (steady state). This level may be continually adjusted for the system to maintain itself. Through direct and indirect connections between the components, changes somewhere in the system have implications for the other parts of the system. This causes the system to be dynamic (De Rosnay, 1975). 
Since the emergence of the systems approach, it has initially been applied to machines and organisms (including applications such as bionics, artificial intelligence, industrial robots), next to business and industry and later to decaying cities and ecology. It did form the basis for the MIT report "Limits to Growth" in the 1970s (De Rosnay, 1975; Meadows et al., 1972). A well-known model of the tourism system was developed in the late 1970s by Leiper (1979). In his view a tourism system is composed of a tourist generating region with push factors, a destination with pull factors, a transit route and departing tourists and returning tourists connecting these elements. Another model of the tourism system was proposed by Mill and Morrison (1985). They perceive tourism to be a system composed of four elements: destination, market and marketing and their interrelations: travel purchase, shape of travel demand, selling of travel and reaching the market place. A more complex model was developed by Walker et al. (1998). They constructed a so-called Tourism Futures Simulator. The simulator model includes over 60 factors and their interrelationships and interdependencies. It helps the actors involved to explore future implications of tourism management and policy options. It shows how economic, social and environmental processes are responding to and being changed by visitor numbers and market segments. Yeoman et al. (2016) provide an example of how soft systems methodology (SSM) (Checkland, 1981) can be used in teaching tourism policy and planning. SSM is a methodology for dealing with complex, interrelated and unstructured problematic situations. It was developed in response to the failure of quantitative analysis to address messy and complex problems. By means of the soft systems approach students learn to systematically analyse policy relationships and to simulate real time problems (Yeoman et al., 2016).

\section{Societies as complex adaptive systems}

The reductionist analytical view is inadequate to understand the functioning and development of society or travel and tourism. The rise of the information society and globalisation since the 1980s has made the world increasingly hyperconnected and interdependent, with unpredictable and surprising effects. The acronym of volatile, uncertain, complex, ambiguous (VUCA) is often used to typify contemporary society. It was the US Army War College that first described the more volatile, uncertain, complex and ambiguous, multilateral world which resulted from the end of the Cold War (Kinsinger and Walch, 2012). While the acronym itself was introduced in the late 1990s and became widely used after the terrorist attacks of 11 September 2001, it has since been popularised by strategic business leaders to describe the chaotic, turbulent and rapidly changing business environment that has become the "new normal". The features of contemporary society of being hyperconnected and VUCA require it to be viewed as a so-called complex adaptive system. This helps to understand how global society lives, changes and adapts to changing circumstances (Miller and Twining-Ward, 2005; Jennings, 2001; Marten, 2001).

\section{Complexity}

The first definitions of complexity were presented in the works of French mathematician Jules Henri Poincare (Pesic, 2013), referring to the irregularities present in dynamic systems. The emergence of complexity was a reaction against the reductionism in modern sciences. From a tourism perspective, complexity relates to how tourism is an open system based upon human activities (Yeoman et al., 2016). From a society perspective, a complex system has the following characteristics. First, a large number of components with a specialised function. Second, the components being hierarchically organised. Third, a huge variety of linkages between the components. Fourth, non-linear interactions and interdependencies (interdependent relations) between the components. These characteristics of a complex system imply that a minor change in one of its components or its interactions induced by an outside force may, via positive and negative feedback loops, have significant impacts as they 
aggregate and amplify over time and that it is difficult to anticipate the outcomes (Baggio, 2006, 2008; De Rosnay, 1975; McLoughlin, 1969).

\section{Adaptivity and resilience}

If a complex system such as society is adaptive (complex adaptive system [CAS]), it has a high degree of self-organising that enables it to maintain or improve its performance. Characteristics of a complex adaptive tourism system (Baggio, 2006, 2008).

- non-determinism: the behaviour of the system cannot be anticipated;

- positive or negative feedback cycles influence the overall behaviour of the system;

- distributed nature: precise localisation of properties and functions impossible because of redundancies and overlaps;

- self-organisation and evolution: once specific parameters pass a threshold unforeseen new properties emerge, the system responds by creating a new structure that reduce its complexity; next, new unforeseen properties emerge until the system reorganises again; thus, external and internal shocks can be absorbed or lead to reorganisation of the system;

- self-similarity: the system will look like itself on a different scale; and

- limited decomposability: impossible to study the properties of the system by decomposing it into functional stable parts.

Cilliers (1998, in Baggio, 2008, p. 5), main properties of a CAS:

- large number of elements;

- interactions among the elements are non-linear and usually have a short range;

- loops in the interactions;

- open relation with the environment of the system;

- far from equilibrium;

- evolution: the future of the system depends on the past one; and

- each element is unaware of the behaviour of the system as a whole and reacts only to locally available information.

Adaptivity is comparable to an endless process of trying to move up with small steps in a hilly landscape whilst the landscape itself is continually changing (Hartman, 2016, 2018). By continuously learning from its environment and adapting, the system evolves, re-finds its balance and becomes resilient to external disturbances (Baggio, 2006, 2008). Holling (1986), Gunderson et al. (1995) view this process as an adaptive cycle, which they present as the infinity symbol in mathematics. Initially the system moves from exploitation to conservation (front left to front right). This involves incremental accumulation of capital, energy, materials and investment. However, gradually the system becomes overconnected, its resilience drops and its vulnerability increases, waiting for an accident to happen. A surprise event (wildcard or Black Swan; Taleb, 2010) may move the system into a state of intense oscillation and chaos, resulting in a collapse and reorientation (back right to back left). The release and reorganisation phase may take place over a short (switch) or a long period of time (progressive change), and it can be local or global. If the outside forces come slowly as a stress factor, it may lead to an evolutionary change of the system. If the outside forces come suddenly as a shock factor, it may lead to a revolutionary transformation. Because of the complex interactions between the components of the system, the process of release and its outcomes are unpredictable. Depending on the degree of disturbance, new actors, inventions, creative ideas, business types, concepts, 
etc. may arise, while others fade away (Miller and Twining-Ward, 2005; Jennings, 2001; Marten, 2001). So, complex adaptive systems' behaviour is completely unpredictable. An expected reaction to an event could induce an utterly unexpected result because of interdependence and homeostasis (De Rosnay, 1975).

However, if the complex system is resilient, it is able to prepare for, to resist and to recover from or to adapt to adverse shocks and stresses, and so to retrieve its balance and retain the same essential function, structure, identity and feedbacks. If the threshold to withstand the external force is not high enough, for example if the resilience of the system has decreased and the system has become more fragile, the external force may pass a tipping point and disrupt the system. In such cases the disruption causes the system to find another level of balance. A ball in a bowl can be used as an example to illustrate the behaviour of complex systems (Figure 1). The position of the ball in the bowl is not static, it can move, but the edges of the bowl ensure it will return to the centre again (re-balance). If resilience is lost and/or the disruptive force is too strong to resist, the ball crosses over the edge of the bowl and ends up at a different level, representing a different state of balance. Complex systems are characterised by periods of stability interspersed by sudden and dynamic perturbation surprising events (wildcards, black swans) (De Rosnay, 1975; Miller and Twining-Ward, 2005).

\section{Subsystem of travel and tourism}

In the hierarchical organised complex adaptive system of global society, travel and tourism is a subsystem that may be regarded as a complex adaptive system in its own right (Miller and Twining-Ward, 2005; Jennings, 2001; Reid, 2003; Baggio and Sainaghi, 2011). McKercher (1999) describes the complex adaptive tourism system as composed of the traveller, communication vectors, considerations, the destination or internal tourism community, external tourism agencies, other tourism related externalities (such as alternative tourism destinations) and non-tourism-related externalities (macro-environmental factors [1] such as natural disasters, changes in consumer behaviour), outputs from the system (both desired and undesired) and rogues or chaos makers. McKercher's model can be applied to the national, regional and local level and even to the level of an enterprise. Viewing, for example, a tourism destination as a complex adaptive system, helps to understand the nature, behaviour and evolution of the destination (Speakman, 2017). This would help a destination management

\section{Figure 1 Resilience explained}

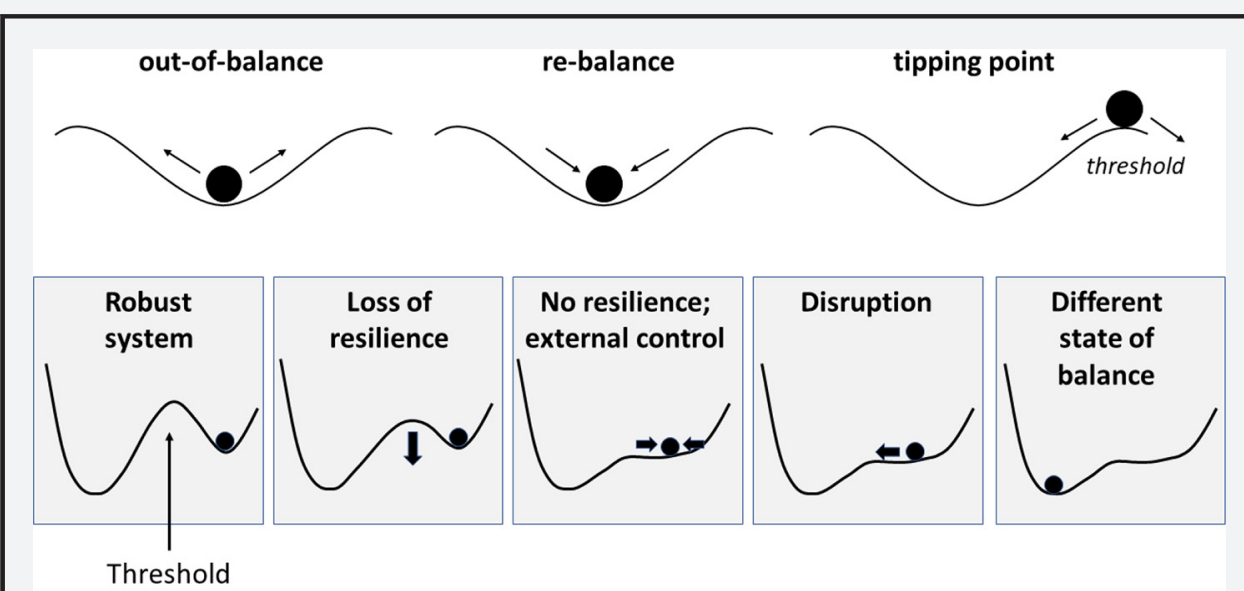

Source: Adapted from Cuijpers (2016) 


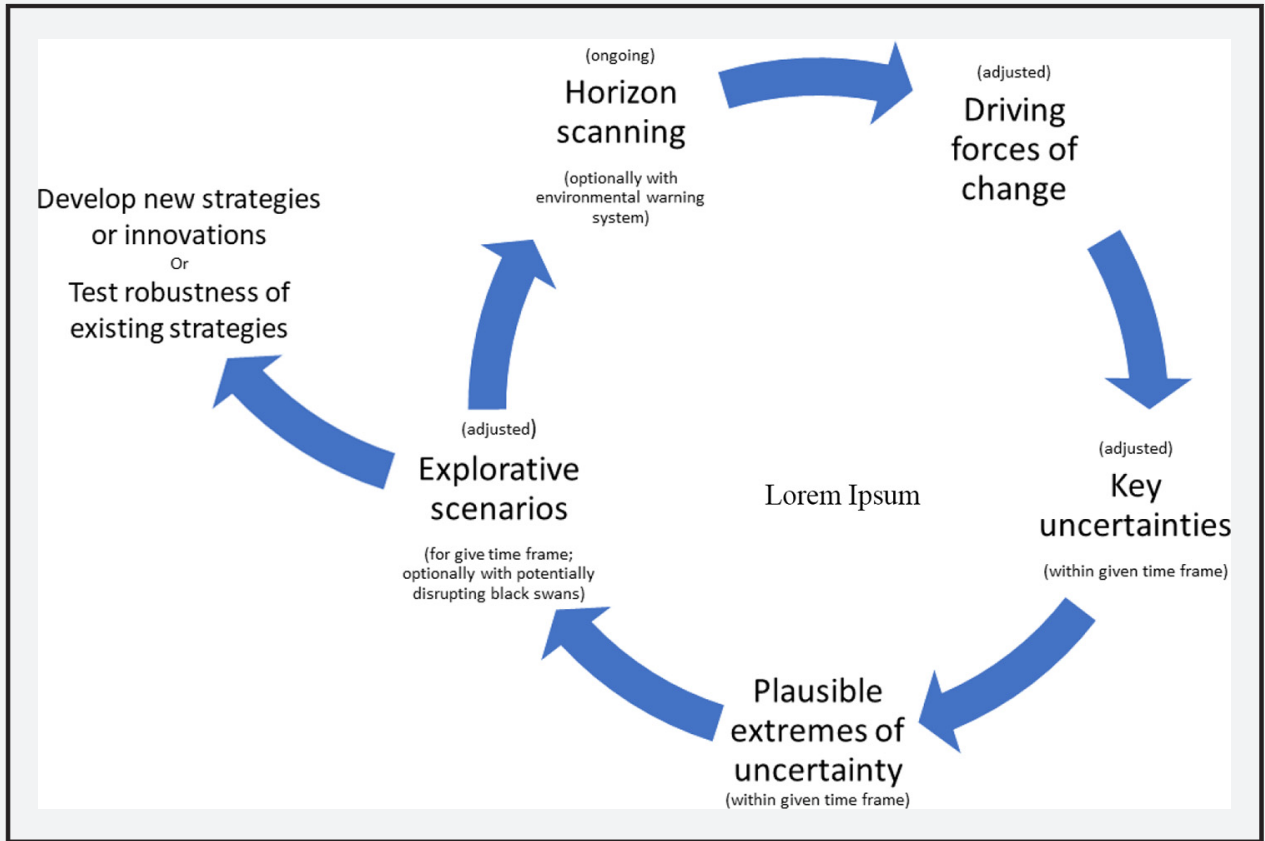

Figure 3 Two management models compared: control model verses model

\section{Control model}

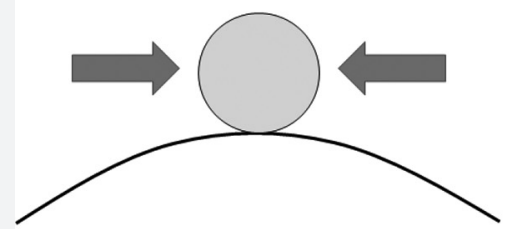

Focus on the problem Variation is switched off Continuous monitoring; direct intervention
Adaptation model

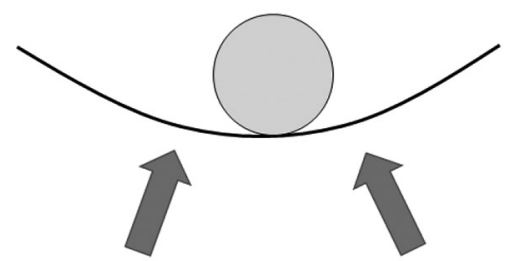

Focus on the system Variation is made use of Self-regulation and adaptive capacity is stimulated; indirect intervention

Static balance

Dynamic balance

organisation to better manage and control a destination (Baggio, 2008), while it can help them to improve their ability to manage crises and disasters (Speakman, 2017). A case study in Acapulco, a tourism destination on the Pacific coast of Mexico did confirm that the failure of policymakers to conceive of the destination as a complex, dynamic and adaptive system resulted in insufficient addressing of many underlying issues and the gradual depletion of its capitals and resources (Speakman and Díaz Garay, 2016).

Despite these advantages, the application of the complex adaptive systems approach to tourism is still in its infancy (Baggio, 2006). Faulkner and Valerio (1995) were among the first to embrace the chaos and complexity framework to explain tourism phenomena and 
Faulkner has applied it in quite a few works subsequently (Baggio, 2008). There are various other examples in which complex adaptive systems have been used to understand the dynamics of tourism destinations and to become more adaptive to outside changes (Baggio, 2008; Baggio and Sainaghi, 2011; Sainaghi and Baggio, 2017; Speakman and Díaz Garay, 2016; Hartman, 2016; Schianetz and Kavanagh, 2008). Nevertheless, even though a complex adaptive systems approach has been widely recommended as a promising interdisciplinary alternative approach to the study of tourism for two decades, actual applications in tourism research have been relatively low (Baggio, 2008; Speakman, 2017).

Like all complex adaptive systems, the travel and tourism system is frequently subject to surprise events (black swans) from the outside with a sudden and unpredictable effect on tourism flows (Baggio and Sainaghi, 2011). In an era analysis the management and research team of NBTC Holland Marketing identified the following transformational forces in recent history of international tourism to The Netherlands: the liberalisation of aviation and the start of low cost carriers (Easyjet) in 1995; the attack on the Twin Towers on 11 September 2001; the emergence of mobile internet and mobile devices (smart phone) in 2007, which was immediately followed by the start of AirBnB; and the economic recession starting in 2008 (Postma and Hartman, 2018). These disruptions caused a discontinuity and transition that marked the ending and beginning of separate periods of relative stability and coherence, with balanced conditions and incremental change (Bishop, 2005).

Past disruptions such as 9/11, the terrorist attacks in Madrid, the bombings in Bali, the SARS epidemic, etc., showed that the self-organisation capacity of the complex adaptive tourism and travel system helped it to recover rapidly to the level before the event (Baggio, 2006). It shows that the system has a remarkable adaptive capacity and resilience when it is hit by a triggering event (Baggio, 2008).

Currently, global travel and tourism is firmly disrupted by the shock wave caused by outbreak of the COVID-19 virus. Three interrelated factors have caused a dramatic decline in international travel: decrease in demand for travel; countries that have closed their borders; and mega events such as Olympic Games in Tokyo, European Football Championships, Formula 1 racing, tours by famous popstars and the Eurovision Song Contest that have been cancelled. The steep drop in international travel put airline companies and accommodations under severe pressure. At tourism destinations it is not only tourist accommodations that suffer from the absence of tourists, it applies to business that are indirectly dependent on tourism as well, such as restaurants, museums, theatres, including suppliers of these businesses. The COVID-19 crisis shows the vulnerability of a system in which all its components are interconnected, interwoven and interdependent. In fact, the entire system of travel and tourism has come squeaky and creaky to a stop. In a special letter Rafat Ali, founder from Skift, wrote that "Travel is the most consequential industry in the world, as it is now finding out owing to lack of travel", 15 March 2020 was "the day the world stopped travelling". (Ali, 2020). Notwithstanding the implications for travel and tourism and the associated visitor economy, it has to be mentioned that the pandemic has positive consequences for the global system as destination recovery strategies focus on sustainability and responsible tourism (Chia-Lin et al., 2020; Duong, 2020; Hassan and Habib, 2020; Strielkowski, 2020; UNWTO, 2020)

\section{Discussion}

The COVID-19 crisis holds up a mirror to us, according to Snowden in an interview in the New Yorker about Snowden's latest book "Epidemics and society: from the black death to the present" (Chotiner, 2020). The crisis raised many questions. Do we start to realise that travel and tourism may have become a patient that needs to be cured? Has the tourism industry, maybe blinded by economic benefits, become too much dependent on international travel? Has the travel and tourism system become too much dependent on 
international corporations? (Reid, 2003). And from the perspective of a complex adaptive system: has international tourism become so massive (as indicated by annoyance of residents in overcrowded destinations) that resilience of the system has decreased and vulnerability for external disruptive forces has increased? How big is the resilience of the current system of travel and tourism? Will the system return to its balance as soon as the COVID-19 virus has been quelled, or will the crisis appear to have been a disruptive force and a game changer that extorts a new balance? Will the crisis cause a reconsideration on international mass tourism? How will politicians, national governments and international corporations position themselves? Does aviation as we know it still fit into a sustainable future of tourism? Will citizens start to reconsider their unrestrained wanderlust? The key question, from a complex adaptive systems perspective, is how a stable travel and tourism industry that aims to maintain and sustain itself, can still change and evolve.

Strategic foresight and scenario planning offer a valuable approach to addressing such questions for the long term. It is based on a collaborative process in which systems thinking, implicitly, plays a key role. During the phases of the process as illustrated in Figure 2, the structure and behaviour of the tourism and travel system is mapped and analysed. Stakeholders with various (disciplinary) backgrounds and interests share, exchange and discuss their expertise, thoughts and perceptions. This helps them to improve their learning capacity, to develop competencies and skills to dealing with uncertainty, such as imagination and outside-the box thinking, and to challenge and stretch their understanding of the structure, behaviour, evolution (including important turning points) and plausible futures of the travel and tourism system (Postma, 2013b; Sainaghi and Baggio, 2017). This may help policymakers and strategists to envision and foresee what could happen with the system in case of specific events and give clues with which the adaptive capacity of the stakeholder in question and the resilience of the travel and tourism system can be improved. A recent example is provided by the Center of Expertise in Leisure, Tourism and Hospitality. A group of academics had been monitoring experts in the media since the beginning of the COVID-19 crisis for a number of weeks, analysed the forcefield driving the travel and tourism system, identified two key uncertainties and developed four explorative future scenarios for the visitor economy: business as usual, survival of the fittest, business as unusual and responsible tourism (Postma et al., 2020). In the strategic foresight process these scenarios are used as inspiration to design and create a desired future (European Foresight Platform, 2010; Lindgren and Bandhold, 2009) (Figure 3).

To conclude, the travel and tourism system may be regarded as a complex adaptive system with unpredictable behaviour. Strategic foresight and scenario planning provide a methodology to monitor and understand the travel and tourism system, to anticipate future developments of the system, to identify strategic courses of action, to contribute to the resilience and sustainability of the travel and tourism system and maintain it in a productive state on the long term. Strategic foresight and scenario planning can be learned. It is a competence that can be used to develop adaptive capacity: to help a destination, organisation or business to adapt and take advantage of natural capacities for resilience, rather than by trying to control it and to prevent change from occurring (Figure 2) (Miller and Twining-Ward, 2005; Louis Bolk Instituut, 2015). According to Ali, the global travel industry is going through existential times. "Travel is the world's largest industry, let's start acting like it! Travel is the geopolitical centre of the world, deal with it!" (Ali, 2020).

\section{Note}

1. Often referred to with the acronym of DESTEP: demographic, economic, social, technological, ecological or political factors (Postma and Papp, 2020). 


\section{References}

Ali, R. (2020), “'The day the world stopped traveling': a letter from Skift's founder'", available at: https:// skift.com/2020/03/15/the-day-the-world-stopped-traveling-a-letter-from-skift-founder/

Baggio, R. (2006), "Complex systems, information technologies and tourism: a network point of view", Information Technology \& Tourism, Vol. 8 No. 1, pp. 15-29.

Baggio, R. (2008), "Symptoms of complexity in a tourism system", Tourism Analysis, Vol. 13 No. 1, pp. 1-20.

Baggio, R. and Sainaghi, R. (2011), "Complex and chaotic tourism systems: towards a quantitative approach", International Journal of Contemporary Hospitality Management, Vol. 23 No. 6, pp. 840-861.

Bezold, C. (2009), "Jim dator's alternative futures and the path to IAF's aspirational futures", Journal of Futures Studies, Vol. 14 No. 2, pp. 123-134.

Bishop, P.C. (2005), "Framework forecasting: managing uncertainty and influence in the future", Second Prague Workshop on Futures Studies Methodology, Charles University, Czech Republic.

Checkland, P. (1981), Systems Thinking: Systems Practice, Wiley \& Sons, Chichester.

Chia-Lin, C., Michael, M. and Vicente, R. (2020), "A charter for sustainable tourism after COVID-19", Sustainability, Vol. 12 No. 3671, p. 3671, doi: 10.3390/su12093671.

Chotiner, I. (2020), "How pandemics change history", New Yorker, available at: www.newyorker.com/ news/q-and-a/how-pandemics-change-history (accessed 3 March 2020).

Cilliers, P. (1998), Complexity and Post-Modernism: understanding Complex Systems, Routlegde, London.

Cuijpers, W. (2016), "Biologisch bodembeheer: werken aan veerkracht in de bodem", Luois Bolk Instituut, Dronten, available at: https://edepot.wur.nl/385013 (accessed 6 September 2019).

Dator, J.A. (Ed.) (2002), Advancing Futures: Futures Studies in Higher Education, Preager, Westport.

Dator, J. (1981), "Alternative futures \& the futures of law", in Dator J. and Bezold, C. (Eds), Judging the Future, University of HI Press, Honolulu, HI, pp. 1-17.

Dator, J. (2009), "Alternative futures at the manoa school”, Journal of Futures Studies, Vol. 1 No. 2, pp. 1-18.

De Rosnay, J. (1975), Le Macroscope. Vers Une Vision Globale, Edition de Seuil, Paris.

Duong, M. (2020), "COVID-19 and after: impact and ways forward", East Asia Forum Quarterly, Vol. 12 No. 2, pp. 31-33.

European Foresight Platform (2010), "What is foresight?", available at: www.foresight-platform.eu/ community/forlearn/what-is-foresight/ (accessed 17 July 2017).

Faulkner, B. and Valerio, P. (1995), "An integrative approach to tourism demand forecasting", Tourism Management, Vol. 16 No. 1, pp. 29-37.

Grech, V. (2020), "Unknown unknowns - COVID-19 and potential global mortality", Early Human Development, Vol. 144, pp. 105026, doi: 10.1016/j.earlhumdev.2020.105026.

Gunderson, L.H., Holling, C.S. and Light, S.S. (1995), "Barriers broken and bridges built: a synthesis", in Gunderson, L.H., Holling, C.S. and Light, S.S. (Eds), Barriers and Bridges to the Renewal of Ecosystems and Institutions, Columbia University Press, New York, NY, pp. 489-532.

Hartman, S. (2016), "Towards adaptive tourism areas? A complexity perspective to examine the conditions for adaptive capacity”, Journal of Sustainable Tourism, Vol. 24 No. 2, pp. 299-314.

Hartman, S. (2018), "Towards adaptive tourism areas: using fitness landscapes for managing tourism area development”, Journal of Tourism Futures, Vol. 4 No. 2, pp. 152-162.

Hassan, S. and Habib, W. (2020), Aspects of Sustainable Tourism Development and COVID-19 Pandemic, Preprints.

Holling, C.S. (1986), "The resilience of terrestrial ecosystems: local surprise and global change", in Clark, W.C. and Munn, R.E. (Eds), Sustainable Development of the Biosphere, Cambridge University Press, Cambridge, pp. 292-317.

Jane, T. (2020), "Fact checking trump's comments on COVID-19 virus", NBC News, available at: www. nbcnews.com/politics/donald-trump/fact-checking-trump-s-comments-COVID-19virus-n1143856

Jennings, G. (2001), Tourism Research, John Wiley and Sons Australia, Milton, Qld. 
Kinsinger, P. and Walch, K. (2012), Living and Leading in a VUCA World, Thunderbird School of Global management, Arizona State University, Phoenix, Arizona.

Leiper, N. (1979), "The framework of tourism: towards a definition of tourism, tourist, and the tourist industry", Annals of Tourism Research, Vol. 6 No. 4, pp. 390-407.

Lindgren, M. and Bandhold, H. (2009), Scenario Planning. The Link between Future and Strategy, 2nd revised and updated edition, Palgrave MacMillan, Basingstoke.

Louis Bolk Instituut (2015), “Jaarverslag 2014”, available at: https://edepot.wur.nl/344956 (accessed 25 November 2019).

McKercher, B. (1999), "A chaos approach to tourism”, Tourism Management, Vol. 20 No. 4, pp. 425-434.

McLoughlin, J.B. (1969), Urban and Regional Planning. A Systems Approach, Faber and Faber, London.

MacKay, R.M. and McKiernan, P. (2004), "The role of hindsight in foresight: refining strategic reasoning", Futures, Vol. 36 No. 2, pp. 161-179.

MacKay, R.M. and Parks, R.W. (2013), "The temporal dynamics of sensemaking: a hindsight-foresight analysis of public commission reporting into the past and future of the "new terrorism", Technological Forecasting and Social Change, Vol. 80 No. 2, pp. 364-374.

Marten, G.G. (2001), Human Ecology - Basic Concepts for Sustainable Development, Earthscan Publications, London.

Meadows, D.H., Meadows, D.L., Randers, J. and Behrens, W.W. (1972), The Limits to Growth, Universe Books, New York, NY.

Mill, R. and Morrison, A. (1985), The Tourism System, Prenctice Hall, Englewood Cliffs, NJ.

Miller, G. and Twining-Ward, L. (2005), Monitoring for a Sustainable Tourism Transition. The Challenge of Developing and Using Indicators, CABI Publishing, Wallingford.

Nathan, M.L. (2004), "How past becomes prologue: a sensemaking interpretation of the hindsightforesight relationship given the circumstances of crisis", Futures, Vol. 36 No. 2, pp. 181-199.

Pesic, P. (2013), "What poincare knew", Science, Vol. 339 No. 6126, pp. 1384-1385, doi: 10.1126/ science. 1235655.

Postma, A. (2013b), "Anticipating the future of European tourism", in: Postma, A. Yeoman, I. and Oskam, J. (Eds), The Future of European Tourism, European Tourism Futures Institute, Leeuwarden, pp. 290-305.

Postma, A. and Hartman, S. (2018), Scenariostudie Inkomend Verblijfstoerisme Nederland, NHL Stenden - European Tourism Futures Institute, Leeuwarden, available at: https://nbtcmagazine.maglr. com/nl_NL/14987/212172/titelblad.html

Postma, A., Heslinga, J. and Hartman, S. (2020), Four Future Perspectives of the Visitor Economy after COVID-19, Center of Expertise in Leisure Tourism and Hospitality, Breda/Leeuwarden/Vlissingen, Retrieved on 28 May 2020 from $\mathrm{g}$.

Postma, A. and Papp, B. (2020), "Of trends and trend pyramids", Journal of Tourism Futures, doi: 10.1108/JTF-11-2019-0129.

Pratt, S. (2020), "A rejoinder to misleading articles about misleading media coverage: a case of COVID19", Anatolia, Vol. 31 No. 3, pp. 514-518, doi: 10.1080/13032917.2020.1774999.

Reid, D. (2003), Tourism, Globalisation and Development: responsible Tourism Planning, Pluto Press, London.

Sainaghi, R. and Baggio, R. (2017), "Complexity traits and dynamics of tourism destinations", Tourism Management, Vol. 63, pp. 368-382.

Schianetz, K. and Kavanagh, L. (2008), "Sustainability indicators for tourism destinations: a complex adaptive systems approach using systemic indicator systems", Journal of Sustainable Tourism, Vol. 16 No. 6, pp. 601-628.

Speakman, M. (2017), "A paradigm for the twenty-first century or metaphorical nonsense? The enigma of complexity theory and tourism research", Tourism Planning \& Development, Vol. 14 No. 2, pp. 282-296. 
Speakman, M. and Díaz Garay, A. (2016), "Perspectives on tourism development planning in acapulco: conventional methods and complexity theory", International Journal of Tourism Sciences, Vol. 16 No. 4, pp. 203-221.

Strielkowski, W. (2020), International Tourism and COVID-19: Recovery Strategies for Tourism Organisations, Preprints, doi: 10.20944/preprints202003.0445.v1.

Taleb, N.N. (2010), The Black Swan: The Impact of the Highly Improbable, 2nd ed., Penguin, London.

UNWTO (2020), "Policy brief: COVID-19 and transforming tourism", available at: MAdrid:https:// webunwto.s3.eu-west-1.amazonaws.com/s3fs-public/2020-08/SG-Policy-Brief-on-COVID-and-Tourism. pdf

Walker, P.A., Greiner, R., McDonald, D. and Lyne, V. (1998), "The tourism futures simulator: a systems thinking approach”, Environmental Modelling \& Software, Vol. 14 No. 1, pp. 59-67.

Yeoman, I., McMahon-Beattie, U. and Wheatley, C. (2016), "Keeping it pure - a pedagogical case study of teaching soft systems methodology in scenario and policy analysis", Journal of Tourism Futures, Vol. 2 No. 2, pp. 175-195, doi: 10.1108/JTF-12-2015-0052.

\section{Corresponding author}

Albert Postma can be contacted at: albert.postma@nhlstenden.com

For instructions on how to order reprints of this article, please visit our website: www.emeraldgrouppublishing.com/licensing/reprints.htm

Or contact us for further details: permissions@emeraldinsight.com 